\title{
AE3 Anion Exchanger Isoforms in the Vertebrate Retina: Developmental Regulation and Differential Expression in Neurons and Glia
}

\author{
Sumire Kobayashi, Catherine W. Morgans, Joseph R. Casey, and Ron R. Kopito \\ Department of Biological Sciences, Stanford University, Stanford, California 94305-5020
}

\begin{abstract}
Plasma membrane anion exchangers constitute a multigene family that contributes to the regulation of intracellular $\mathrm{pH}$ and chloride concentration in many cell types. We have characterized two polypeptide isoforms of the AE3 gene that are expressed in the rat retina. Using antipeptide antibodies specific for defined $\mathrm{NH}_{2}$-terminal and $\mathrm{COOH}$-terminal epitopes, we have identified a $165 \mathrm{kDa}$ polypeptide whose expression is restricted to the primary glial cell type of the retina, the Müller cell, and a $125 \mathrm{kDa}$ polypeptide that is expressed in horizontal neurons. Expression of the Müller cell isoform exhibits a polarized distribution and is highest in basal endfoot processes. These AE3 isoforms exhibit a distinct developmental expression pattern in postnatal rat retina. The neuronal isoform is undetectable in neonatal retina until postnatal day $10-15$, correlating strongly with the onset of retinal function.
\end{abstract}

[Key words: intracellular $\mathrm{pH}$, retina, horizontal cell, neuron, Müller cell, glia, anion, anion exchange, chloride, bicarbonate]

The vertebrate retina is notable for having extremely high rates of aerobic metabolism and oxygen consumption (Warburg, 1926; Futterman and Kinoshita, 1959; Rodieck, 1988). For optical reasons, the retina is sparsely vascularized (Walls, 1942), and efficient elimination of the considerable $\mathrm{CO}_{2}$ and $\mathrm{H}^{+}$load from photoreceptor activity is necessary to maintain intracellular and extracellular $\mathrm{pH}$ homeostasis. Several aspects of the phototransductive cascade are sensitive to $\mathrm{pH}$. For instance, experimentally imposed acidosis decreases photoreceptor light-sensitive current (Sillman et al., 1972; Gedney and Ostroy, 1978), slows down response kinetics (Liebman et al., 1984), and reduces the content of cGMP in photoreceptors (Meyertholen et al., 1986). Additionally, ion channels that participate in visual signal transduction are influenced by intracellular or extracellular protons. In lower vertebrates, connectivity among horizontal cells, which contributes to center-surround organization by providing a feedback loop to cones (Baylor et al., 1971), is mediated by gap

\footnotetext{
Received Jan. 21, 1994; revised Apr. 15, 1994; accepted Apr. 21, 1994.

We thank Russell Fernald, Steven DeVries, and all of the members of the Kopito laboratory for critical reading of the manuscript. We are grateful to $G$. Shull and S. Linn for the gift of the rat cardiac AE3 plasmid. We are indebted to $\mathrm{C}$. $\mathrm{W}$. Heizmann and $\mathrm{C}$. Barnstable for antibodies. This work was supported by grants from the National Institutes of Health (GM38543), the American Heart Association, and the American Cancer Society. J.R.C. is supported by a Postdoctoral Fellowship from the Medical Research Council of Canada. R.R.K. is an Established Investigator of the American Heart Association.

Correspondence should be addressed to Ron R. Kopito at the above address. Copyright (C) 1994 Society for Neuroscience $0270-6474 / 94 / 146266-14 \$ 05.00 / 0$
}

junctions that are exquisitely sensitive to small changes in intracellular $\mathrm{pH}$ within the physiological range (DeVries and Schwartz, 1989). Intracellular $\mathrm{pH}$ also regulates high-voltageactivated $\mathrm{Ca}^{2+}$ currents (Takahashi et al., 1993) and NMDAtype glutamate receptor currents (Christensen and Hida, 1990) in fish horizontal cells. Similarly, extracellular acidification suppresses a $\mathrm{Ca}^{2+}$ current in cones that may contribute to neurotransmitter release (Barnes and Bui, 1991). Modulatory effects of internal and extracellular protons are not limited to neurons. For example, transport of a pH-changing anion accompanies glutamate uptake by Müller glia, suggesting that $\mathrm{pH}$ might affect the kinetics of termination of neurotransmitter action (Bouvier et al., 1992). All these findings support the notion that regulation of intracellular and extracellular $\mathrm{pH}$ is critical for proper functioning of the retina.

Neuronal activity in the retina, as in other excitable tissues, leads to changes in intracellular and extracellular $\mathrm{pH}$ (for reviews, see Chesler, 1990; Kaila, 1992). Metabolic production of $\mathrm{H}^{+}$equivalents by photoreceptors creates a standing gradient of extracellular pH across the cat (Yamamoto et al., 1992) and toad (Oakley and Wen, 1989) retina that is highest in the outer nuclear layer immediately surrounding the photoreceptor perikarya. Stimulation by light evokes a transient alkalinization of sufficient magnitude to modulate the activity of $\mathrm{pH}$-sensitive ion channels (Oakley and Wen, 1989; Yamamoto et al., 1992). Glutamate stimulation of horizontal cells induces a transient intracellular acidification (Dixon et al., 1993) that suppresses a high-voltage-activated $\mathrm{Ca}^{2+}$ current, and could modulate the gating of gap junctions. Permeation of $\mathrm{HCO}_{3}{ }^{-}$through GABAgated anion channels leads to transient fall in intracellular $\mathrm{pH}$ (Kaila and Voipio, 1987) and a rise in extracellular $\mathrm{pH}$ (Chen and Chesler, 1990), suggesting a link between synaptic inhibition and $\mathrm{pH}$ regulation. Synaptic activity, therefore, evokes transient changes in both intracellular and extracellular $\mathrm{pH}$ of magnitudes sufficient to influence the response properties of neuronal circuits.

The magnitude and duration of such $\mathrm{pH}$ transients depend on the intracellular and extracellular buffering capacity and the activity of plasma membrane acid and base transporters in neurons and glia (for reviews, see Chesler, 1990; Chesler and Kaila, 1992). Extracellular pH in intact retina is sensitive to amiloride (Oakley and Wen, 1989), an inhibitor of $\mathrm{Na}^{+} / \mathrm{H}^{+}$exchange, and to the disulfonic stilbenes DIDS and SITS (Cabantchik and Rothstein, 1972), which block plasma membrane $\mathrm{HCO}_{3}{ }^{-}$transporters including $\mathrm{Na}^{+} / \mathrm{HCO}_{3}-$ cotransporter (Jentsch et al., 1984), and $\mathrm{Na}^{+}$-dependent and $\mathrm{Na}^{+}$-independent $\mathrm{Cl}^{-} / \mathrm{HCO}_{3}{ }^{-}$exchangers (Cabantchik and Greger, 1992). Treatment with in- 
hibitors of carbonic anhydrase or experimental superfusion of retinas with bicarbonate-free buffers alters extracellular $\mathrm{pH}$, attenuates the b-wave of the electroretinogram, and reduces rod saturating response amplitude and rod cGMP content (Donner et al., 1990). Application of DIDS to intact frog retina reversibly abolishes photoresponses in a $\mathrm{pH}$-dependent manner (Donner et al., 1990). These types of experiments support the hypothesis that bicarbonate transporters contribute to retinal function by maintaining intracellular and extracellular $\mathrm{pH}$. Because of the poor specificities of transport inhibitors and the difficulty of measuring $\mathrm{pH}$ transients in physically inaccessible compartments that are not in rapid equilibrium with bulk extracellular water, the molecular details of retinal $\mathrm{pH}$ regulation, and the contributions thereto of individual cell types, remain largely uninvestigated.

To begin to construct a map of proton trafficking in the CNS it is necessary to complement physiological studies with a precise definition of the types of $\mathrm{pH}$ regulatory transporters present, their biophysical properties, and their cellular and subcellular localization. As a first step toward this goal, our laboratory has been studying a family of structurally related anion exchangers that catalyze the tightly coupled, electroneutral exchange of the two principal cellular anions, $\mathrm{Cl}^{-}$and $\mathrm{HCO}_{3}{ }^{-}$(reviewed in $\mathrm{Ko}-$ pito et al., 1990). Despite their structural homologies, which are reflected in similar catalytic properties, the physiological roles and regulation of anion exchangers differ widely among cell types. For example, in erythrocytes, the $\mathrm{AE} 1$ anion exchanger facilitates the transport of plasma $\mathrm{CO}_{2}$ by allowing the rapid equilibration of $\mathrm{HCO}_{3}$ - between the intracellular and extracellular compartments (reviewed in Knauf, 1986). Coupled $\mathrm{Cl}^{-} /$ $\mathrm{HCO}_{3}{ }^{-}$and $\mathrm{Na}^{+} / \mathrm{H}^{+}$exchange leads to net $\mathrm{NaCl}$ transport, and is the basis of the regulatory volume response of many cells to osmotic shrinkage (Grinstein et al., 1984; Hebert, 1986). Anion exchangers also operate as alkali extruders, which regulate $\mathrm{pH}_{i}$ in many cell types including epithelia (Machen and Paradiso, 1987), cultured cell lines (Chaillet et al., 1986; Kurtz and Golchini, 1987), lymphocytes (Mason et al., 1989), and smooth muscle (Aickin and Brading, 1982). Finally, cardiac Purkinje fibers use an unidentified anion exchanger to maintain intracellular $\mathrm{Cl}^{-}$above electrochemical equilibrium (Vaughan-Jones, 1978). In a previous report, we used molecular cloning to identify a novel plasma membrane anion exchanger gene, AE3, that is expressed chiefly in brain and heart (Kopito et al., 1989). However, there has been to date no description of the location of AE 3 polypeptides in any tissue. We report here that both the cardiac and brain isoforms of AE 3 are expressed - in a developmentally regulated manner-in specific neuronal and glial cell types in the neural retina of the rat.

\section{Materials and Methods}

$m R N A$ isolation. Tissues used for RNA isolation were isolated from female Sprague-Dawley rats and rapidly frozen in liquid nitrogen. Tissues ( 60 retinas, two hearts, and two brains) were homogenized by grinding in a mortar and pestle under liquid nitrogen. PolyA RNA was directly isolated using oligo-dT-cellulose (Boehringer Mannheim), according to Badley et al. (1988).

Northern blots. PolyA RNA ( $5 \mu \mathrm{g}$ retina, $4 \mu \mathrm{g}$ brain, and $2.5 \mu \mathrm{g}$ heart) was denatured with formaldehyde and formamide and resolved on $0.9 \%$ agarose gels, as described by Sambrook et al. (1989), except that the concentration of formaldehyde was reduced to $0.22 \mathrm{M}$ in the gel and buffer. RNA standards $(0.24-9.5 \mathrm{~kb}$ ladder, GIBCO-Bethesda Research Labs) were included in neighboring lanes. RNA was transferred to nylon membrane (Hybond-N, Amersham) and cross-linked to the membrane with ultraviolet light at $120 \mathrm{~mJ} / \mathrm{cm}^{2}$ (Stratalinker, Stratagene, Inc.). Blots were prehybridized for 4 hr at $42^{\circ} \mathrm{C}$ in $50 \%$ formamide, $5 \times \mathrm{SSC}, 1 \times$ Denhardt's, $1 \%$ sodium dodecyl sulfate, $50 \mu \mathrm{g} / \mathrm{ml}$ sheared salmon sperm DNA, and $20 \mathrm{~mm}$ sodium phosphate, $\mathrm{pH}$ 6.6. Blots were hybridized for $16 \mathrm{hr}$ at $42^{\circ} \mathrm{C}$ in $10 \mathrm{ml}$ of $50 \%$ formamide, $5 \times \mathrm{SSC}, 1 \times$ Denhardt's, $1 \%$ sodium dodecyl sulfate, $50 \mu \mathrm{g} / \mathrm{ml}$ sheared salmon sperm DNA, $10 \%$ dextran sulfate, and $20 \mathrm{~mm}$ sodium phosphate, $\mathrm{pH} 6.6$, containing $2 \times$ $10^{6} \mathrm{cpm} / \mathrm{ml}$ of probe. Blots were washed $2 \times 15 \mathrm{~min}$ at room temperature in $2 \times \mathrm{SSC}, 0.2 \% \mathrm{SDS}$, followed by $30 \mathrm{~min}$ at $65^{\circ} \mathrm{C}$ in $0.2 \times \mathrm{SSC}$, and then $0.2 \%$ SDS. Autoradiography was performed using preflashed Kodak XAR film and an enhancing screen.

Hybridization probes. A probe for the unique exon found in cardiac AE 3 was isolated by PCR. Cardiac AE3 plasmid (gift from Dr. Gary Shull), linearized with Bst XI, was used as a PCR template. A 159 base pair portion of the exon was amplified for 30 cycles using the primers 5' GCTCCCACAGGCCATAGT 3' and 5' ACAAGGTCATGGAGCCCA $3^{\prime}$. Annealing temperature was $55^{\circ} \mathrm{C}$ and elongation was performed at $72^{\circ} \mathrm{C}$ for $15 \mathrm{sec}$, using Vent DNA polymerase (New England Biolabs). Plasmid pBSL108, coding for mouse AE3 (Kopito et al., 1989), was digested with Apa I. The fragment corresponding to nucleotides 1864 2459 was isolated from a low-melting-point agarose gel and purified using $\beta$-agarase (New England Biolabs), following the manufacturer's instructions. The 159 bp PCR product was also isolated by gel purification and $\beta$-agarase treatment. Radioactive probes were prepared by random hexamer labeling (Pharmacia) (Feinberg and Vogelstein, 1983) using $\alpha{ }^{32} \mathrm{P} \mathrm{dCTP}$ (New England Nuclear) to a specific activity of $2 \times$ $10^{9}$ cpmir $\mu \mathrm{g}$.

Enzymatic deglycosylation. Freshly isolated rat tissues were homogenized either in a polytron (one heart) or by 12 strokes of a Dounce homogenizer (eight retinas) in $5 \mathrm{ml}$ of ice-cold $0.32 \mathrm{M}$ sucrose, $1 \mathrm{~mm}$ EGTA, $0.1 \mathrm{~mm}$ EDTA, $10 \mathrm{~mm}$ HEPES, pH 7.5, containing $200 \mu \mathrm{M}$ PMSF, $100 \mu \mathrm{M}$ TLCK, $200 \mu \mathrm{M}$ TPCK, $1 \mu_{\mathrm{M}}$ leupeptin, and $100 \mu \mathrm{M}$ benzamidine. Homogenates were centrifuged at $2510 \mathrm{rpm}$ for $5 \mathrm{~min}$ at $4^{\circ} \mathrm{C}$ in a Sorvall SS34 rotor. The supernatant was removed and centrifuged at $30,000 \mathrm{rpm}$ for $30 \mathrm{~min}$ at $4^{\circ} \mathrm{C}$ in a Beckman Ti70 rotor. The resulting membrane fraction was resuspended in phosphate-buffered saline and either used for deglycosylation experiments directly or stored frozen at $-70^{\circ} \mathrm{C}$. To heart membranes (97 $\mu \mathrm{g}$ protein) and retina membranes (40 $\mu$ g protein) in $13.8 \mu \mathrm{l}$ of PBS, containing the protease inhibitors used to isolate the membranes, was added $1.3 \mu \mathrm{l}$ of $5 \%$ SDS and $10 \% 2$-mercaptoethanol. Proteins were denatured by incubation for 10 min at $60^{\circ} \mathrm{C}$. Samples were diluted by addition of $9 \mu \mathrm{l}$ of $5 \% \mathrm{NP}-40$ in $0.25 \mathrm{~m}$ sodium citrate, $\mathrm{pH} 7.5$. To each sample was added either $20 \mu \mathrm{l}$ of $N$-glycosidase-F (1000 U/ $\mu$; New England Biolabs) or $20 \mu \mathrm{l}$ of water. Samples were incubated for $2.5 \mathrm{hr}$ at $37^{\circ} \mathrm{C}$.

Antibodies. Polyclonal antibodies AP- 3 and AP- 6 were generated against synthetic tridecapeptides corresponding to amino acids 1215 and 195, respectively, of mouse AE3 (Kopito et al., 1989). Peptides were conjugated via glutaraldehyde to PPD (Statens Scruminstitut, Copenhagen) (Doolittle, 1987), and then emulsified in Freund's adjuvant. This emulsion, containing $500 \mu \mathrm{g}$ of conjugate, was used to immunize New Zealand White rabbits. Rabbits were boosted with $250 \mu \mathrm{g}$ of conjugate after 3 weeks and every 3 weeks thereafter. Sera were tested on immunoblots of AE3-transfected HEK cells (Kopito et al., 1989). Highest titer bleeds were affinity purified on peptide Sepharose columns [using activated $\mathrm{CH}$-sepharose $4 \mathrm{~B}$ (Pharmacia) according to the manufacturer's instructions], eluted with glycine- $\mathrm{HCl}, \mathrm{pH} 2.5$, neutralized, dialyzed, concentrated on Centricon-30 (Amicon) filters, and stored at $4^{\circ} \mathrm{C}$ with sodium azide $(0.02 \%)$. Antibody AP-3 was used at a concentration of $0.0067 \mu \mathrm{g} / \mathrm{ml}$ in immunoblots and $0.005 \mu \mathrm{g} / \mathrm{ml}$ for immunocytochemistry. Antibody AP- 6 was used at a concentration of 0.001 $\mu \mathrm{g} / \mathrm{ml}$ in immunoblots and $0.04 \mu \mathrm{g} / \mathrm{ml}$ for immunocytochemistry, Monoclonal antibodies to calbindin $28 \mathrm{k}$ (generous gift of Dr. Claus Heizmann, Zürich) and 8A1.75 ascites (gift of Dr. Colin Barnstable, Yale University) were used at dilutions of $1: 2000$ and 1:20,000, respectively. Monoclonal antibodies to vimentin (catalog \#V 6630) and GFAP [clone G-A-5 (Debus et al., 1983), catalog \#3893] were obtained from Sigma (St. Louis, MO) and used at dilutions of 1:50,000 and 1:400, respectively.

Immunoblots. HEK cells were transfected with AE3 as previously described (Lee et al., 1991). Membranes were isolated as described above, suspended in Laemmli sample buffer, heated for $5 \mathrm{~min}$ at $60^{\circ} \mathrm{C}$, and resolved on a $7 \%$ SDS gel (Laemmli, 1970). Proteins were transferred to nitrocellulose (Schleicher and Schuell, Keene, NII) by electrophoresis in buffer composed of $10 \%(\mathrm{v} / \mathrm{v})$ methanol, $12.4 \mathrm{~mm}$ Tris, and $96 \mathrm{~mm}$ glycine for $2 \mathrm{hr}$ at $24 \mathrm{~V}$ using a Genie Blotter (Idea Scientific, Minneapolis, MN). Nitrocellulose strips were blocked by incubation for 


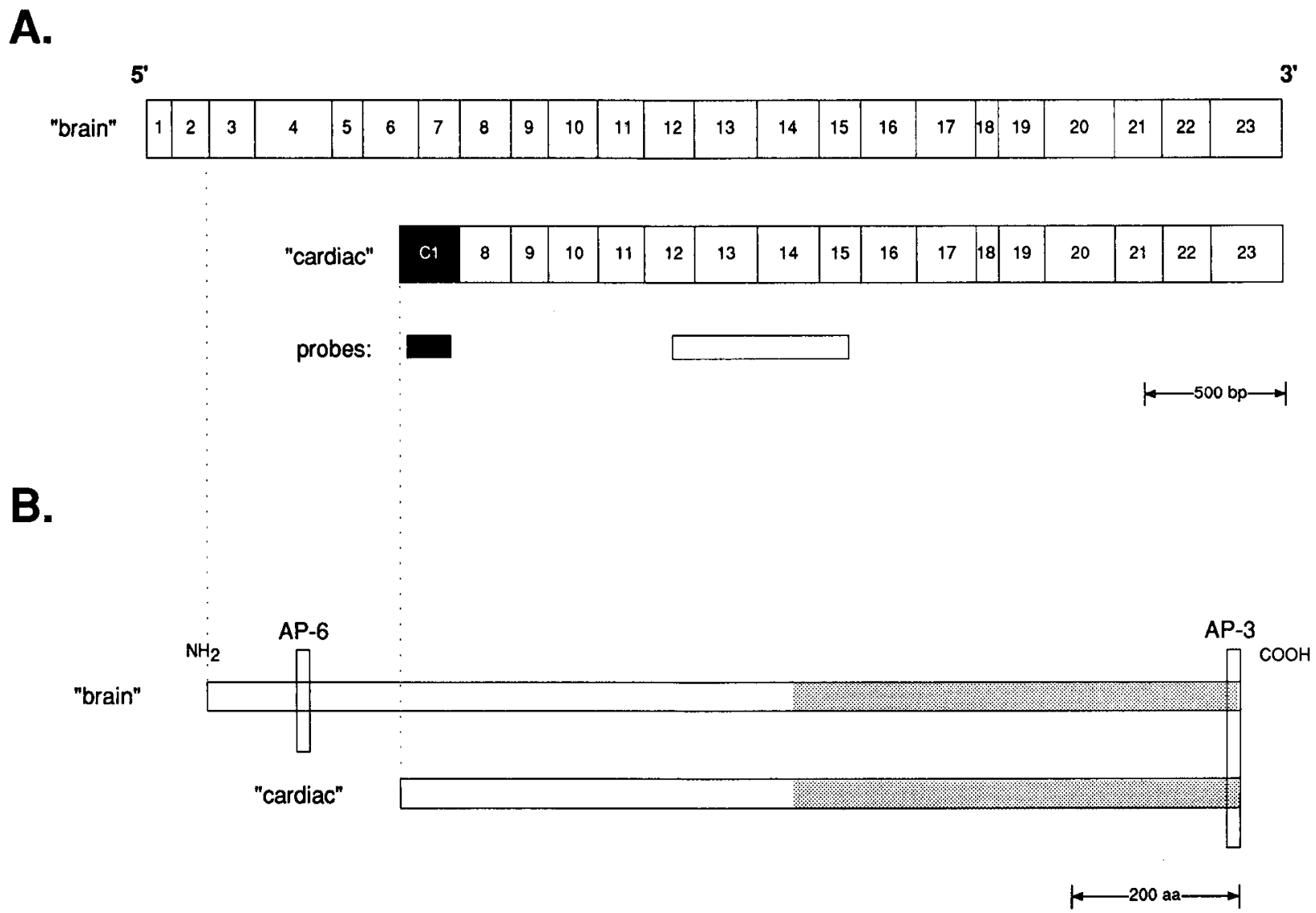

Figure 1. Organization of AE3 transcripts and their corresponding polypeptides. $A$, The numbered boxes correspond to individual exons in the rat AE3 gene (Linn et al., 1992). The black box labeled C1 refers to the exon previously shown to be present in cardiac AE3 but absent from the brain isoform (Linn et al., 1992). Location of the two cDNA probes used for Northern analysis in Figure 2 is indicated. $B$, The corresponding polypeptides encoded by the "brain" and "cardiac" cDNAs are designated by the long horizontal boxes. Shaded area corresponds to the membraneassociated domain. Vertical boxes indicate the location of the peptides against which the AP-6 and AP-3 antibodies were generated.

$30 \mathrm{~min}$ in $20 \mathrm{~mm}$ Tris, $137 \mathrm{~mm} \mathrm{NaCl}$, and $5 \%(\mathrm{w} / \mathrm{v})$ nonfat dry milk, $\mathrm{pH} 7.6$, incubated in primary antibody at $25^{\circ} \mathrm{C}$ for $2 \mathrm{hr}$ or $4^{\circ} \mathrm{C}$ overnight, and followed by horseradish peroxidase-conjugated donkey anti-rabbit IgG for $75 \mathrm{~min}$ at $25^{\circ} \mathrm{C}$. Blots were developed with ECL reagent (Amersham) and exposed to XAR film (Kodak).

Histology. Adult Sprague-Dawley rats were anesthetized with ether and fixed by transcardiac perfusion with phosphate-buffered saline (PBS; $140 \mathrm{~mm} \mathrm{NaCl}, 8 \mathrm{~mm}$ phosphate buffer, $\mathrm{pH} 7.40$ ) followed by $4 \%$ paraformaldehyde in PBS. Eyes were hemisected, and the retinas removed and postfixed for $4 \mathrm{hr}$ at $4^{\circ} \mathrm{C}$, and then infiltrated with $20 \%$ sucrose prior to freezing and sectioning. Frozen sections $(15 \mu \mathrm{m})$ were processed either transversely (vertical sections) or tangentially (horizontal sections) on a cryostat and collected onto gelatin-coated slides. Sections were either used immediately or stored under desiccant at $-70^{\circ} \mathrm{C}$. For immunostaining, sections were rehydrated in PBS, blocked and permeabilized in $5 \%$ bovine serum albumin and $0.3 \%$ Triton X-100 for $30 \mathrm{~min}$ at $25^{\circ} \mathrm{C}$, and incubated with primary antibody overnight at $4^{\circ} \mathrm{C}$. Sections were subsequently washed in PBS, incubated with fluorescein-conjugated goat anti-rabbit (Zymed) or rhodamine-conjugated goat anti-mouse (Molecular Probes) for $1 \mathrm{hr}$ at $25^{\circ} \mathrm{C}$, and, after extensive washing, stained with bisbenzamide $(2 \mu \mathrm{g} / \mathrm{ml})$ for $1 \mathrm{~min}$ and mounted in $90 \%$ glycerol $/$ $10 \%$ PBS supplemented with $2.5 \%$ DABCO [1,4-diazabicyclo $(2,2,2)$ octane]. Stained sections were photographed on an Axiophot (Zeiss) microscope with a $40 \times$ Neofluor objective (1.3 NA) (see Figs. $4,6,9,10)$ on Ektachrome P800 film, or with a Bio-Rad confocal microscope (see Figs. 5, 7, 8). Confocal micrographs were acquired using a $63 \times$ Neofluor (1.4 NA). Image files were cropped and laid out with PHOTOSHOP (version 2.5, Adobe Systems) and PAGEMAKER (Aldus). All confocal images were acquired as linear averages of 8-12 consecutive scans. No other image enhancement was used.

Retinal dissociation and densitometry. Retinas from adult SpragueDawley rats were enzymatically dissociated by the method of Sarthy and Lam (1979) as modified by McGrail and Sweadner (1986). Dis- sociated cells were fixed for $30 \mathrm{~min}$ at room temperature by resuspension in $2 \%$ paraformaldehyde in $100 \mathrm{~mm}$ sodium phosphate buffer, $\mathrm{pH} 7.4$. Fixed cells were washed with $1 \mathrm{ml}$ phosphate buffer ( $100 \mathrm{~mm}, \mathrm{pH} 7.4)$, and spread on gelatin-coated slides prior to air drying. Immunostaining was performed as described above, except that the primary antibodies were applied for $1 \mathrm{hr}$ at room temperature. Densitometry of the immunoblot shown in Figure 10 was obtained by image analysis using the NIH IMAGE software (version 1.44). An 8-bit gray scale image was scanned at 300 dots per inch using a ScanJet Plus scanner (HewlettPackard) into a TIFF file. The scanner response was calibrated using a Kodak gray scale wedge. All images used for quantifying Figure 10 were within the linear response of the film and scanning densitometry.

\section{Results and Discussion}

Two AE3 isoforms are expressed in rat retina

The two major AE3 species transcribed from the single rat AE3 gene are depicted in Figure 1. Alternative promoter utilization gives rise to $4.3 \mathrm{~kb}$ and $3.8 \mathrm{~kb}$ transcripts in brain and heart, respectively (Linn et al., 1992). Both transcripts encode polypeptides predicted to possess the entire membrane-associated anion transport domain, differing only at the extreme $\mathrm{NH}_{2}$ terminal 270 amino acids. Northern blots were performed to determine the number and size of AE3 transcripts expressed in rat heart, brain, and retina (Fig. 2, lanes 1-3). A band of approximately $4.3 \mathrm{~kb}$ was detected in all three tissues using a probe containing exons 12-15 of mouse AE3. Its mobility corresponds well with the predicted size of the major brain AE3 transcript (Fig. 1). In this region the nucleotide sequences of mouse and 

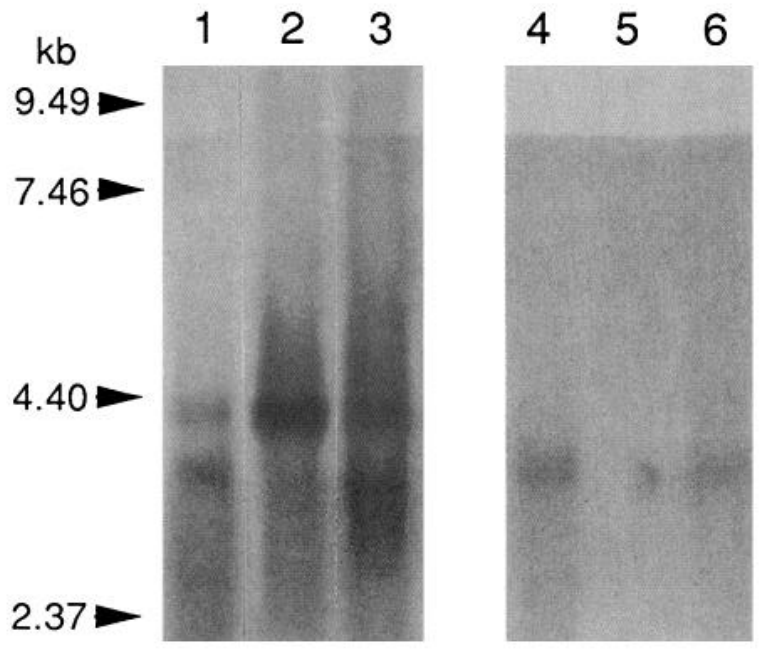

Figure 2. Northern blot analysis of AE3 transcripts. Blots of polyA $\mathrm{A}^{+}$ RNA from heart (lanes 1, 4), brain (lanes 2, 5), and retina (lanes 3, 6) of adult rat were hybridized with a probe from AE3 exons 12-15 (lanes $1-3$ ) or from exon $\mathrm{C} 1$ (lanes 4-6). The small blob in lane 5 corresponds to a crease in the membrane filter, not to probe hybridization.

rat AE3 are $93.5 \%$ identical. An additional transcript of $\sim 3.8$ $\mathrm{kb}$ was observed in heart and retina, but not brain mRNA. This latter band hybridizes uniquely to a probe derived from exon "C1," which was shown by Linn et al. (1992) to contain the cap site and initiation AUG for the $3.8 \mathrm{~kb}$ major cardiac AE3 isoform (Fig. 2, lanes 4-6). We conclude that rat retina mRNA contains both of the major AE3 transcripts that are depicted schematically in Figure 1.

In order to identify polypeptides corresponding to both AE3 mRNAs, polyclonal antibodies were generated against synthetic peptides corresponding to $\mathrm{COOH}$ - and $\mathrm{NH}_{2}$-terminal AE3 regions as depicted in Figure $1 B$. Both antibodies recognized a $150 / 165 \mathrm{kDa}$ doublet in immunoblots of extracts of HEK cells transfected with mouse brain AE3 cDNA (Kopito et al., 1989) (Fig. 3A, lanes 1, 4). The larger of these two bands corresponds to the size of the mature polypeptide in retina. The smaller band corresponds to a glycosylation intermediate. These data indicate that both affinity-purified antibodies recognize the authentic AE3 polypeptide.

Immunoblots of SDS-soluble retinal proteins probed with the $\mathrm{COOH}$-terminal antibody AP-3 revealed two major polypeptides at 165 and $125 \mathrm{kDa}$ and a minor band at $\sim 190 \mathrm{kDa}$ (Fig. $3 A$, lane 2). The $165 \mathrm{kDa}$ and $190 \mathrm{kDa}$ bands were also recognized by the $\mathrm{NH}_{2}$-terminal AP-6 antibody (Fig. 3A, lane 5). Based on its mobility and its reactivity with both antibodies, we conclude that the $165 \mathrm{kDa}$ band is the polypeptide encoded by the larger of the two retinal transcripts, and corresponds to the major "brain" AE3 isoform (see Fig. 1). The $190 \mathrm{kDa}$ may be a minor AE3 isoform hitherto undetected by mRNA analysis because it reacts with both AE3 antibodies. The $110 \mathrm{kDa}$ band that is recognized by AP-6 in retina (Fig. $3 A$, lane 5) is either a cross-reactive, unrelated protein or an AE3 isoform that lacks the $\mathrm{COOH}$-terminal epitope. The $125 \mathrm{kDa}$ band is not recognized by the AP- 6 antibody, consistent with its being encoded by the "cardiac" isoform that lacks the exon containing the AP-6 epitope (Fig. $3 A$, lane 5). However, the $125 \mathrm{kDa}$ band in retina migrates more slowly on SDS-PAGE than does the major cardiac AE3 band (Fig. 3A, lane 3), which is also not recognized by the AP-6 antibody (Fig. 3A, lane 6).
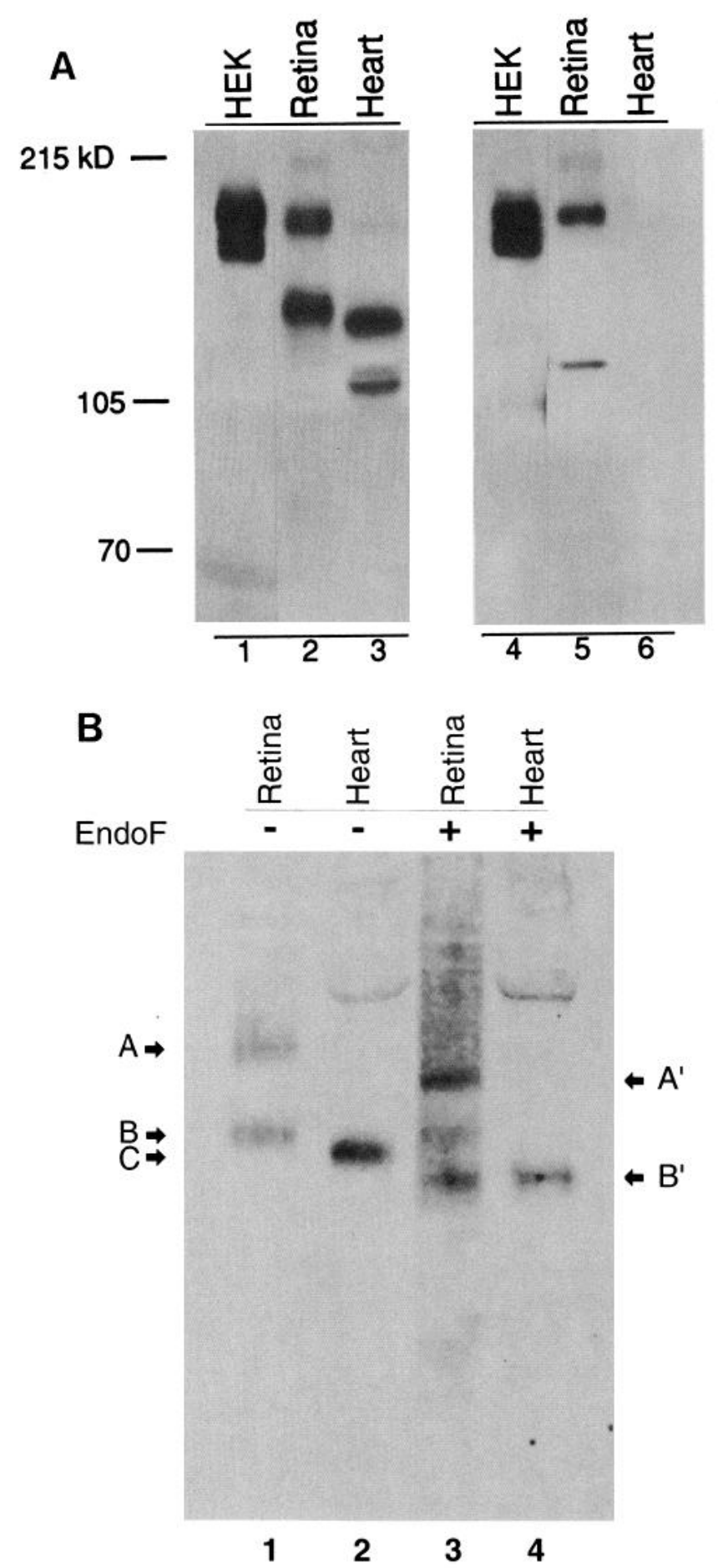

Figure 3. Expression and deglycosylation of AE3 polypeptides. A, SDSsoluble proteins from HEK cells transfected with the brain form of AE3 (lanes 1, 4), or retina (lanes 2, 5), or heart (lanes 3,6) from adult rat were probed with antibody AP-3 (lanes 1-3) or antibody AP-6 (lanes 4-6). In $B$, proteins from retina or brain were either subjected to enzymatic deglycosylation (lanes 3,4 ) or control conditions (lanes 1, 2).

Since the $3.8 \mathrm{~kb}$ transcripts in heart and retina contain the same "cardiac" exon, we examined whether the difference in electrophoretic mobilities of the two AE3 proteins may arise from tissue-specific differences in posttranslational modification of the same polypeptide. Crude membranes from heart and retina were solubilized in detergent and treated with $\mathrm{N}$-glycosidase-F to remove all $\mathrm{N}$-linked oligosaccharide chains. 
A.

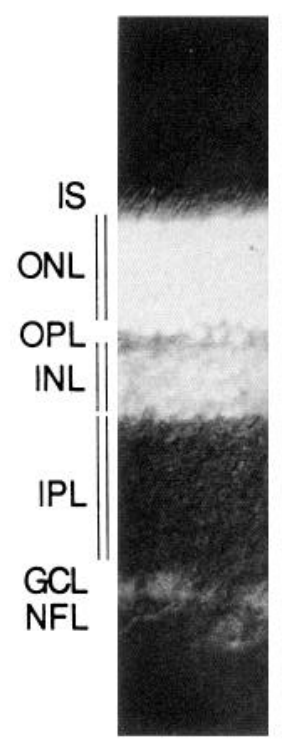

B.

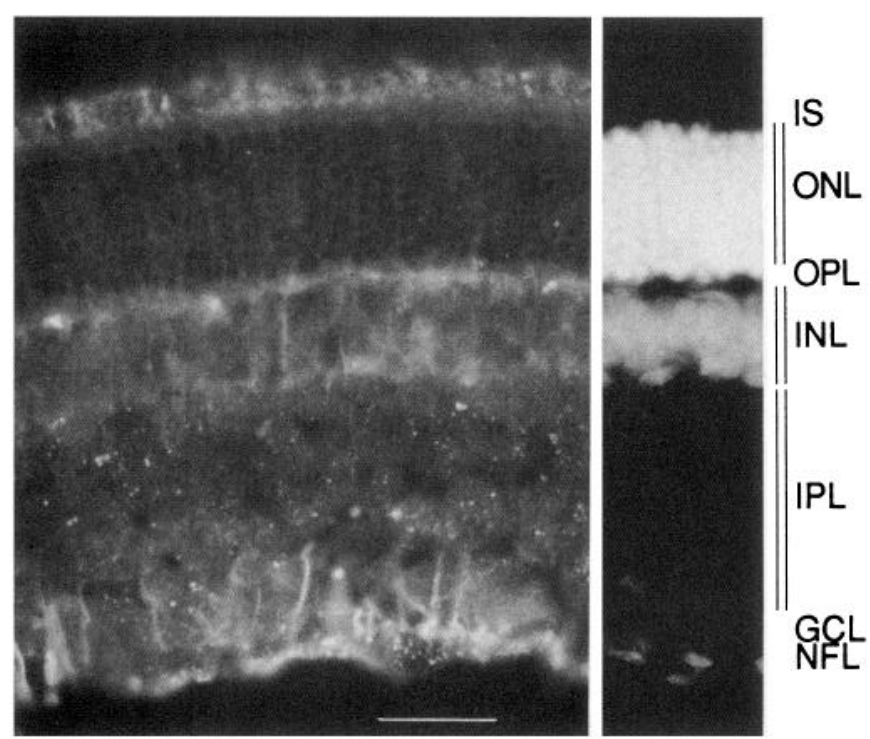

Figure 4. Localization of AE3 in retinas from adult rat. Frozen vertical sections of retina were labeled with antibodies AP-3 (A) or AP-6 (B) and visualized by fluorescence microscopy. Sections were also stained with bisbenzamide to identify the three nuclear layers. Scale bar, $50 \mu \mathrm{m}$.

An immunoblot of the treated samples, probed with antibody AP-3, is shown in Figure $3 B$. Deglycosylation of heart membranes resulted in the disappearance of the major cardiac AE3 band (Fig. 3B, lane 2, band $\mathrm{C}$ ) and concomitant appearance of a faster-migrating species (Fig. $3 B$, lane 4 , band $B^{\prime}$ ), indicating complete deglycosylation of the cardiac polypeptide. $\mathrm{N}$-glycosidase-F treatment of retinal membranes resulted in the appearance of two species (Fig. $3 B$, lane $3, A^{\prime}$ and $B^{\prime}$ ), suggesting that nearly all of the band A material and some of the band B material had been deglycosylated. Since the mobilities of the deglycosylated AE3 from retina and heart are similar, we conclude that tissue-specific differential glycosylation of the same primary AE3 polypeptide accounts for the difference in AE3 mobility between heart and retina. It is not clear whether this modification has any functional consequences. Deglycosylation of the closely related erythrocyte band 3 (AE1) anion exchanger has no detectable effect on its functional properties or its oligomeric state (Casey et al., 1992). Together, these data allow us to conclude that polypeptides corresponding to both the "brain" and "cardiac" isoforms of the AE3 gene are expressed in retina from adult rat.

\section{The two AE3 isoforms are expressed in distinct retinal layers}

Frozen sections of rat retina were examined by fluorescence immunocytochemistry using affinity-purified antibodies (Fig. 4). Staining with antibody AP-3 (Fig. $4 A$ ) revealed strong immunoreactivity in the outer plexiform layer (OPL) and along the inner margin of the retina in the nerve fiber layer (NFL). Similar distribution of AP-3 staining was observed in sections from either central or peripheral (not shown) retina. By contrast, no staining of the OPL was detected with the AP- 6 antibody. Reactivity with this antibody in the nerve fiber layer, however, appeared identical to that obtained with antibody AP-3. The simplest interpretation of these data is that the "brain" AE3 isoform, which was detected as a $165 \mathrm{kDa}$ polypeptide on immunoblots and contains epitopes for both antibodies (Fig. 3), is expressed in the NFL, and the "cardiac" isoform, which is manifested on immunoblots as a $125 \mathrm{kDa}$ polypeptide and lacks the AP-6 epitope (Fig. 3), is expressed in the OPL.

\section{The $165 \mathrm{kDa}$ "brain" AE3 isoform is expressed in retinal Müller cells}

To determine the identity of the AE3-expressing cell type in the nerve fiber layer, retinas were stained with AE3 antibody (AP3) together with antibodies against protein markers for intermediate filament proteins characteristic of well defined retinal cell types. In rat, GFAP antibodies label both major classes of retinal macroglia: astrocytes and Müller cells' (Björklund et al., 1985; McGrail and Sweadner, 1986; Stone and Dreher, 1987). In confocal sections of adult rat retina, staining with a monoclonal GFAP antibody was observed in thick parallel processes running along the length of the NFL, typical of astrocyte staining (Björklund et al., 1985; Stone and Dreher, 1987), and in thinner processes emanating across the radial axis of the retina throughout the inner nuclear layer (Fig. $5 B$, arrows). These radial processes are characteristic of Müller cell staining (Dräger et al., 1984; Björklund et al., 1985; Robinson and Dreher, 1990). AE3 (AP-3 antibody) staining in the same section, observed sequentially (to avoid any fluorescent "spillover" between rhodamine and fluorescein channels) in the confocal microscope, was present in the OPL and in only the radially projecting subset of GFAP-positive fibers. Vimentin is an intermediate filament protein that in rodent retina is present in Müller cells and, to a lesser extent, horizontal cells (Shaw and Weber, 1983, 1984;

\footnotetext{
'Although GFAP is frequently considered to be absent from Müller cells of normal retina in most species (Dixon and Eng, 1981; Shaw and Weber, 1983), some GFAP antibodies, including the one used in this study (Debus et al., 1983), do appear to label Müller cells in normal adult rat (Björkland et al., 1985; Stone and Dreher, 1987) and mouse (Huxlin et al., 1992) retina. These discrepancies most likely reflect gross differences in the levels of GFAP expression between astrocytes and Müller cells. Alternatively, they could arise from the presence of multiple isoforms of GFAP generated by alternative mRNA splicing or from transcription of a family of GFAP-related intermediate filament genes. In either case, our data in retinal sections and dissociated cells demonstrate that GFAP, or at least the epitope recognized by the GA-5 mAb, is present in Müller cells from adult rat.
} 

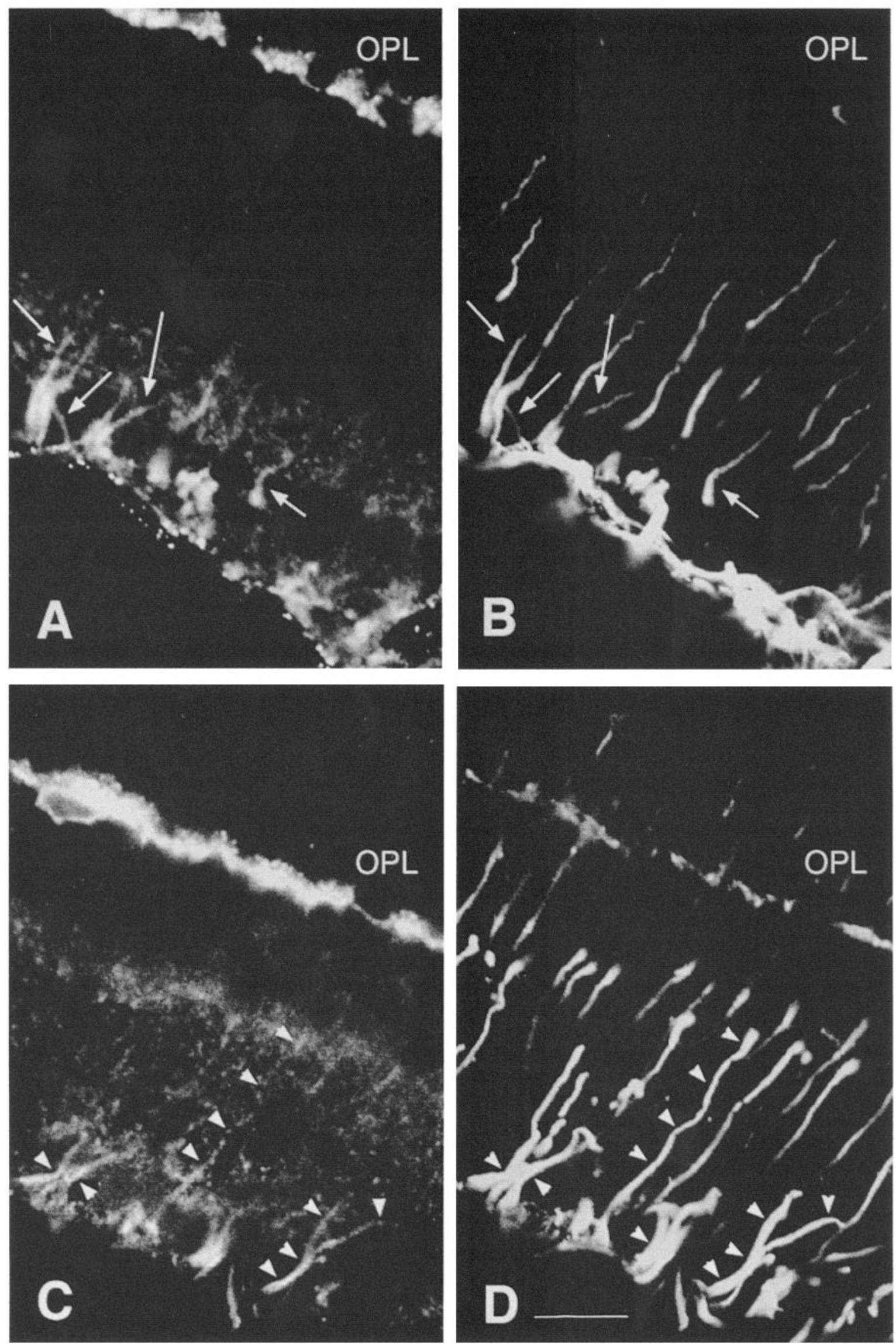

Figure 5. Colocalization of AE3 immunofluorescence with intermediate filaments in inner retina. Confocal microscopy was used to visualize AE3 $(A, C)$ and GFAP $(B)$ or vimentin $(D)$. $O P L$, outer plexiform layer. Scale bar, $25 \mu \mathrm{m}$. 
Robinson and Dreher, 1990). Monoclonal antibody to vimentin reacted with the radial but not the parallel processes, consistent with data from other investigators showing that vimentin is expressed in Müller cells. Weak vimentin staining was also present in cells in the outer plexiform layer (Fig. 5D), consistent with expression of this intermediate filament protein in horizontal cells. All of the vimentin-positive radial processes were double labeled with antibodies to AE3 (Fig. $5 C$, arrowheads). The coincidence of the AE3 with GFAP- and vimentin-immunoreactive radial fibers suggests that AE3 is expressed in Müller cells.

To confirm this hypothesis, retinas from adult rats were enzymatically dissociated, and examined by phase-contrast and immunofluorescent microscopy for the presence of morphologically and immunologically identifiable cell types. Müller cells were abundant in these preparations and readily identifiable by the presence of an elongated cell body and eccentric nucleus (Fig. 6). All morphologically identified Müller cells were strongly positive for GFAP (Fig. 6B) and vimentin (Fig. 6D). All Müller cells thus identified were also strongly positive for both the AP-3 (Fig. 6A,C) and the AP-6 (Fig. 6E,F) epitopes. Furthermore, no other cells types in the dissociated cell preparations were AP-6 positive, despite the occasional observation of presumptive astrocytes that were positive for GFAP (but negative for AE3). Together, these data demonstrate that AE3 is expressed in retinal Müller cells. The presence of both AP-3- and AP-6-immunoreactive epitopes in Müller cells and the lack of immunoreactivity of the AP-6 antibody in outer plexiform layer strongly support the conclusion that the "brain" $165 \mathrm{kDa}$ form of AE3 is restricted in retina to Müller cells. The absence of AE3 immunoreactivity from GFAP-positive astrocyte processes and from dissociated retinal astrocytes suggests that Müller cells are the only AE3-expressing macroglial cell type in retina.

\section{The $125 \mathrm{kDa}$ "cardiac" AE3 isoform is expressed in retinal horizontal cells}

A similar strategy was used to identify the AE3-positive cell type in the outer plexiform layer. Vertical and horizontal frozen sections of retina were stained with AE3 antibody together with a monoclonal antibody against a $28 \mathrm{kDa} \mathrm{Ca}{ }^{2+}$-binding protein (CalBP-28K) (Röhrenbeck et al., 1987). The CalBP-28K monoclonal labels both classes of horizontal cell and some amacrine cells in the adult retina (Celio and Heizmann, 1981; Röhrenbeck et al., 1987). Confocal images of adult retina stained with CalBP$28 \mathrm{~K}$ antibody (Fig. $7 B, D$ ) confirmed that this antibody labels the processes and the somata of horizontal cells in the OPL. In vertical sections of retina, AE3 labeling (Fig. $7 \mathrm{~A}$ ) corresponded well to the pattern obtained with CalBP-28K (Fig. $7 B$ ). Figure 7, $C$ and $D$, shows serial reconstructions (representing the linear sum of eight $1 \mu \mathrm{m}$ optical sections) of a horizontal section of retina through the OPL. CalBP-28K can be observed to label the somata and processes of horizontal cells. AE3 distribution in the same reconstruction was more extensive and was highly punctate. One cell body (Fig. $7 C, D$, arrowheads) was stained with both antibodies. However, the AE3 staining appeared to surround but not cover the nuclear region, suggesting that, unlike cytosolic CalBP-28K, AE3 is restricted to the plasma membrane. These data suggest that the $125 \mathrm{kDa}$ "cardiac" isoform of AE3 is expressed in horizontal cells. Staining of retinal sections with AP-3 together with monoclonal antibody 8A1.75 against the $68 \mathrm{kDa}$ neurofilament subunit and a marker for horizontal cell processes in the OPL (Dräger et al., 1984) also supported the conclusion that AE3 is expressed in horizontal cells (data not shown).

To confirm the presence of AE3 in horizontal cells, acutely dissociated retinal cells were examined for expression of the AP3-reactive epitope and horizontal cell markers. As shown in Figure 8, dissociated 8A1.75-positive (Fig. 8B) and CalBP-28Kpositive (Fig. $8 D$ ) cells were also strongly immunoreactive with the AP-3 antibody. AE3 staining in dissociated cells was punctate and associated with cell processes, similar to what was observed in the confocal images of horizontal retinal sections (Fig. 7). To confirm the identity of the AE3 isoforms in retinal cells, two different fields of dissociated cells were stained with antibodies to CalBP-28K (Fig $9 B, D$ ) and with the two AE3 antibodies (Fig. 9A,C). As expected, AP-3 (Fig. 9A) stained both horizontal cells and Müller cells, while AP-6 (Fig. 9C) stained only the Müller cell, confirming the absence of AP-6 epitopes from horizontal cells. Taken together, the above data establish that the "cardiac" $125 \mathrm{kDa}$ isoform of AE3 is expressed in retinal horizontal cells.

\section{Expression of two AE3 isoforms in retina during postnatal development}

Retinal cell differentiation and synaptogenesis in the rat continue until eye opening, which occurs during the second postnatal week (Sidman, 1961; Weidman and Kuwabara, 1969; Blanks and Bok, 1977; Carter-Dawson and LaVail, 1979; Young, 1985). We used immunoblotting to investigate whether AE3 expression is developmentally regulated, and whether it is correlated with any of the physiological and morphological changes that accompany the late acquisition of photoresponsiveness. Retinas, collected at various days postnatally, were dissolved in SDS-PAGE sample buffer. Each lane of the immunoblot shown in Figure $10 \mathrm{~A}$ was loaded with an equal amount of total retinal protein. The blot was probed with antibody AP-3 in order to label both isoforms. Figure $10 B$ shows in graphical form the relative intensities of the $125 \mathrm{kDa}$ and $165 \mathrm{kDa}$ bands obtained by scanning densitometry and digitization of the immunoblot. The Müller cell AE3 isoform (165 kDa) is present at extremely low levels at PN3 but rises steadily to reach nearly adult levels by PN15. By contrast, there was no evidence for expression of the horizontal cell form (125 kDa) until PN15, even after overexposure of the immunoblot. Between PN15 and PN20, corresponding to the time at which the rat's eyes began to open, the $125 \mathrm{kDa}$ AE3 isoform accumulated to $70 \%$ of adult level. These data show that the cardiac AE3 isoform is a very late marker for horizontal cell differentiation. Together with our immunohistochemical analysis of adult (Figs. 4-9) and devcloping (not shown) rat retina, our data establish that both AE3 isoforms are under separate cell-type-specific and developmental regulation.

\section{Two isoforms of AE3 are expressed in distinct cell types in rat retina}

The data presented here establish that rat retina contains two isoforms of AE3 that are present in distinct populations of neuronal and glial cells. Using mRNA analysis and antipeptide antibodies specific for defined $\mathrm{NH}_{2}$-terminal and $\mathrm{COOH}$-terminal peptides, we have identified a $165 \mathrm{kDa}$ polypeptide whose expression is restricted to the primary glial cell type of the retina, the Müller cell, and a $125 \mathrm{kDa}$ polypeptide that is expressed in horizontal neurons. These two isoforms correspond to those previously designated as "brain" and "cardiac," and are derived 

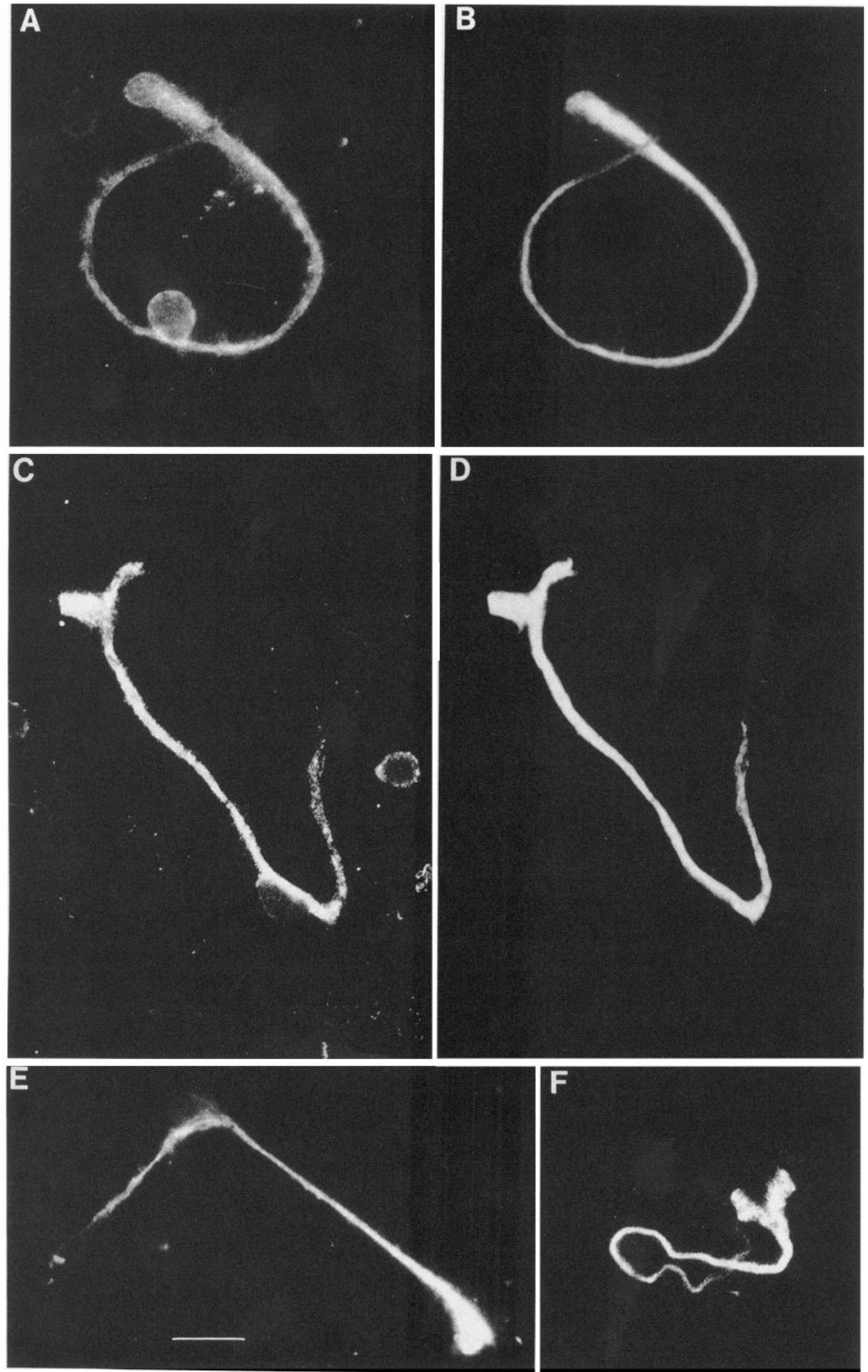

Figure 6. AE3 is expressed in dissociated Müller cells. Müller cells were isolated from adult rat retina and stained with antibody AP-3 ( $A$, $C$ ) and antibodies to either GFAP $(B)$ or vimentin $(D)$. Müller cells in $E$ and $F$ were stained only with antibody AP-6. Scale bar, $10 \mu \mathrm{m}$. 


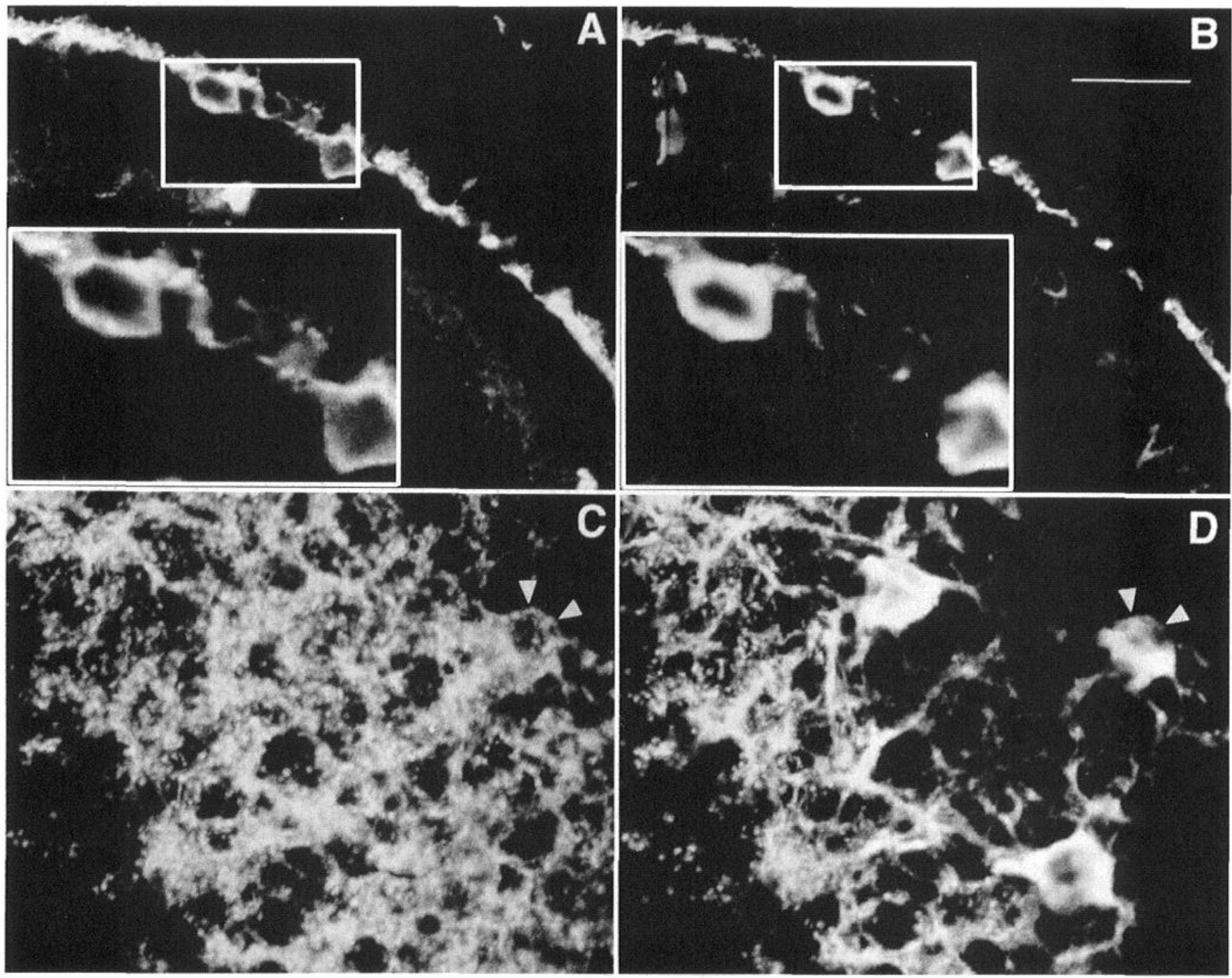

Figure 7. Localization of AE3 and calbindin 28k immunofluorescence in the outer plexiform layer. Confocal microscopy was used to visualize staining of vertical $(A, B)$ or horizontal $(C, D)$ sections of adult rat retinas with antibody AP-3 $(A, C)$ or antibody to calbindin $28 \mathrm{k}(B, D)$. Scale bar: $25 \mu \mathrm{m}$ for $A$ and $B, 50 \mu \mathrm{m}$ for insets, $37.5 \mu \mathrm{m}$ for $C$ and $D$.

from the single AE3 gene by alternate promoter utilization (Linn et al., 1992). Expression of these AE3 isoforms exhibits a distinct pattern of expression late in postnatal development of the rat retina. The restricted expression of these two isoforms in specific cell types has functional implications for the retina that are discussed below.

\section{Functional significance of AE3 expression in Müller glia}

Müller cells (MC) are the principal macroglial elements of the vertebrate retina and are generally assumed to participate in the control of ions and solutes in the extracellular spaces surrounding neurons (Newman, 1986c). Consistent with this role, MC elaborate fine processes that invest neurons in all retinal layers, particularly in regions of high synaptic density such as the plexiform layers (Robinson and Dreher, 1990). MC are the only cell type to span the entire thickness of the retina; apical processes at the outer limiting membrane surround the photoreceptor inner segments and basal "end feet" contact vitreous humor and blood vessels (Robinson and Dreher, 1990). This arrangement is consistent with the proposed role for Müller cells in the spatial buffering of extracellular $\mathrm{K}^{+}$. According to this model,
$\mathrm{K}^{+}$, released into the extracellular spaces surrounding synapses in the plexiform layers, is absorbed by the surrounding Müller processes and "siphoned" into the blood and vitreous through $\mathrm{K}^{+}$channels that are enriched in the end feet (Newman, 1986a,b). Müller cells contain high levels of carbonic anhydrase, consistent with their proposed role in the regulation of $\mathrm{CO}_{2}$ and $\mathrm{pH}$ (Bhattacharjee, 1976; Linser et al., 1984). The retina is poorly (or, in some species, not at all) vascularized and diffusion alone may not be sufficient to remove efficiently the $\mathrm{CO}_{2}$ produced by the photoreceptors. Cytoplasmic carbonic anhydrase can "trap" $\mathrm{CO}_{2}$ released by photoreceptors intracellularly by converting it to intracellular $\mathrm{HCO}_{3}{ }^{-}$and $\mathrm{H}^{+}$. Transporters located in the Müller cell end feet could facilitate the removal into the vitreous or the blood of $\mathrm{H}^{+}$and $\mathrm{HCO}_{3}{ }^{-}$. In support of this model, Newman has recently described electrophysiological evidence for a stilbene-sensitive $\mathrm{Na}^{+} / \mathrm{HCO}_{3}{ }^{-}$cotransporter functionally localized to the end feet of salamander Müller cells (Newman, 1991). AE3 distribution appears to be polarized near the end-foot region of Müller cells, when examined in cryosections. This polarity is less pronounced, however, in dissociated cells, possibly reflecting a rapid redistribution of the protein on 

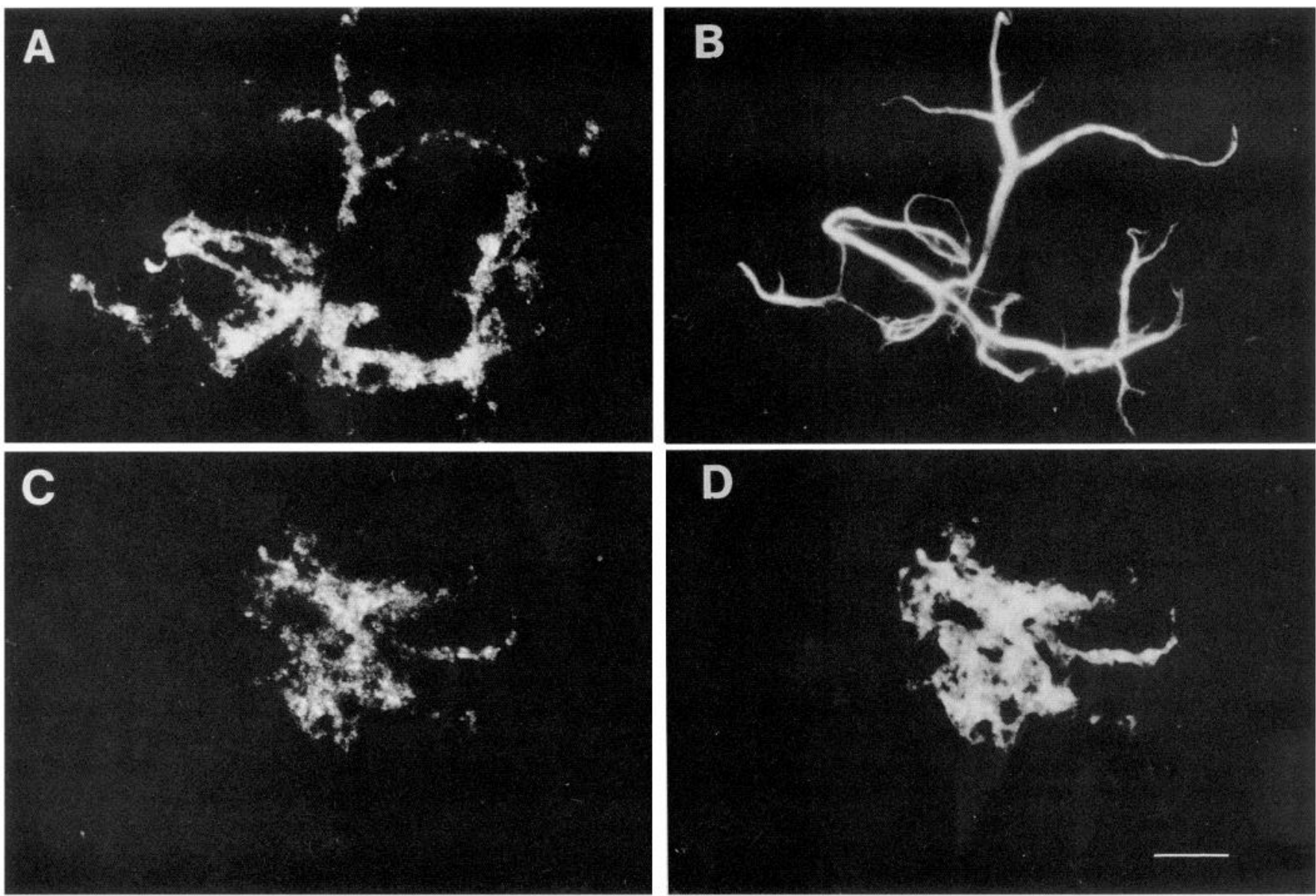

Figure 8. AE3 is expressed in dissociated horizontal cells. Horizontal cells were isolated from adult rat retina and stained with antibody AP-3 $(A, C)$ and antibodies to either neurofilament $(B)$ or calbindin $28 \mathrm{k}(D)$. Scale bar, $10 \mu \mathrm{m}$.

the cell surface during isolation. One possible role for AE3, which we have previously shown to function as a $\mathrm{Cl}^{-} / \mathrm{HCO}_{3}^{-}$ exchanger (Kopito et al., 1989), is to participate in a process of " $\mathrm{CO}_{2}$ siphoning" by providing an additional efflux mechanism for $\mathrm{HCO}_{3}{ }^{-}$.

AE3 can also contribute to the maintenance of Müller cell cytoplasmic $\mathrm{pH}$ by exchanging intracellular $\mathrm{HCO}_{3}-$ for extracellular $\mathrm{Cl}^{-}$. Light-evoked $\mathrm{pH}_{\mathrm{o}}$ changes have been recorded in intact retina and are sensitive to carbonic anhydrase inhibitors and to SITS (Oakley and Wen, 1989; Donner et al., 1990), an AE3 antagonist (Kopito et al., 1989), consistent with a physiological role for $\mathrm{HCO}_{3}{ }^{-}$transport in retinal $\mathrm{pH}$ maintenance. Müller cells possess $\mathrm{Na}^{+}$-coupled transporters that contribute to the termination of synaptic transmission by removing the neurotransmitters GABA and glutamate from the synaptic terminal. Glutamate uptake by salamander Müller cells is accompanied by a countertransported $\mathrm{pH}$-changing anion (either $\mathrm{OH}^{-}$ or $\mathrm{HCO}_{3}^{-}$) (Bouvier et al., 1992). AE3 could help to maintain Müller cell $\mathrm{pH}_{\mathrm{i}}$ by exchanging this countertransported alkali equivalent for extracellular $\mathrm{Cl}^{-}$. Any direct contribution of anion exchangers to $\mathrm{HCO}_{3}^{-}$efflux would result in an obligatory rise in $\mathrm{Cl}^{-}$. Thus, AE3 might also serve to maintain the level of intracellular $\mathrm{Cl}^{-}$above electrochemical equilibrium, potentially affecting the activity of $\mathrm{Cl}^{-}$-dependent transporters such as those for GABA and taurine (Kanner, 1993).

Our data and those of others indicate that MC are functionally polarized with respect to the distribution of AE3, suggesting the existence in these cells of a mechanism for sorting and intracellular targeting of plasma membrane proteins to specific membrane domains. Association with ankyrin has been proposed to be involved in the establishment of polarized distributions of amiloride-sensitive $\mathrm{Na}^{+}$channel (Smith et al., 1991) and $\mathrm{Na}^{+} /$ $\mathrm{K}^{+}$ATPase in epithelia (Nelson and Veshnock, 1987), of voltage-gated $\mathrm{Na}^{+}$channel in specialized regions of the axolemma (McKeon et al., 1986), and of the $\mathrm{Na}^{+} / \mathrm{Ca}^{2+}$ exchanger in sarcolemma (Li et al., 1993). We have recently demonstrated that AE3 possesses the capacity to bind ankyrin (Morgans and Kopito, 1993), raising the possibility that ankyrin association contributes to AE3 polarity in MC. At least two immunoreactive isoforms of ankyrin can be immunologically detected in rat retina (C. W. Morgans and R. R. Kopito, unpublished observations); it remains to be demonstrated that one of these ankyrins colocalizes with AE3, and, more importantly, that interaction with ankyrin in Müller cells contributes to the polarized distribution of AE3.

\section{Functional significance of AE3 expression in horizontal cells}

Horizontal cells (HC) are second-order neurons that integrate visual information over large areas of the retina (for reviews, see Dowling, 1987; Wassle and Boycott, 1991). HC differ from other neurons in several important respects. Like the photoreceptors, from which they receive primary synaptic input, $\mathrm{HC}$ respond to light with graded changes in membrane potential; they do not fire action potentials. They express antigens such 

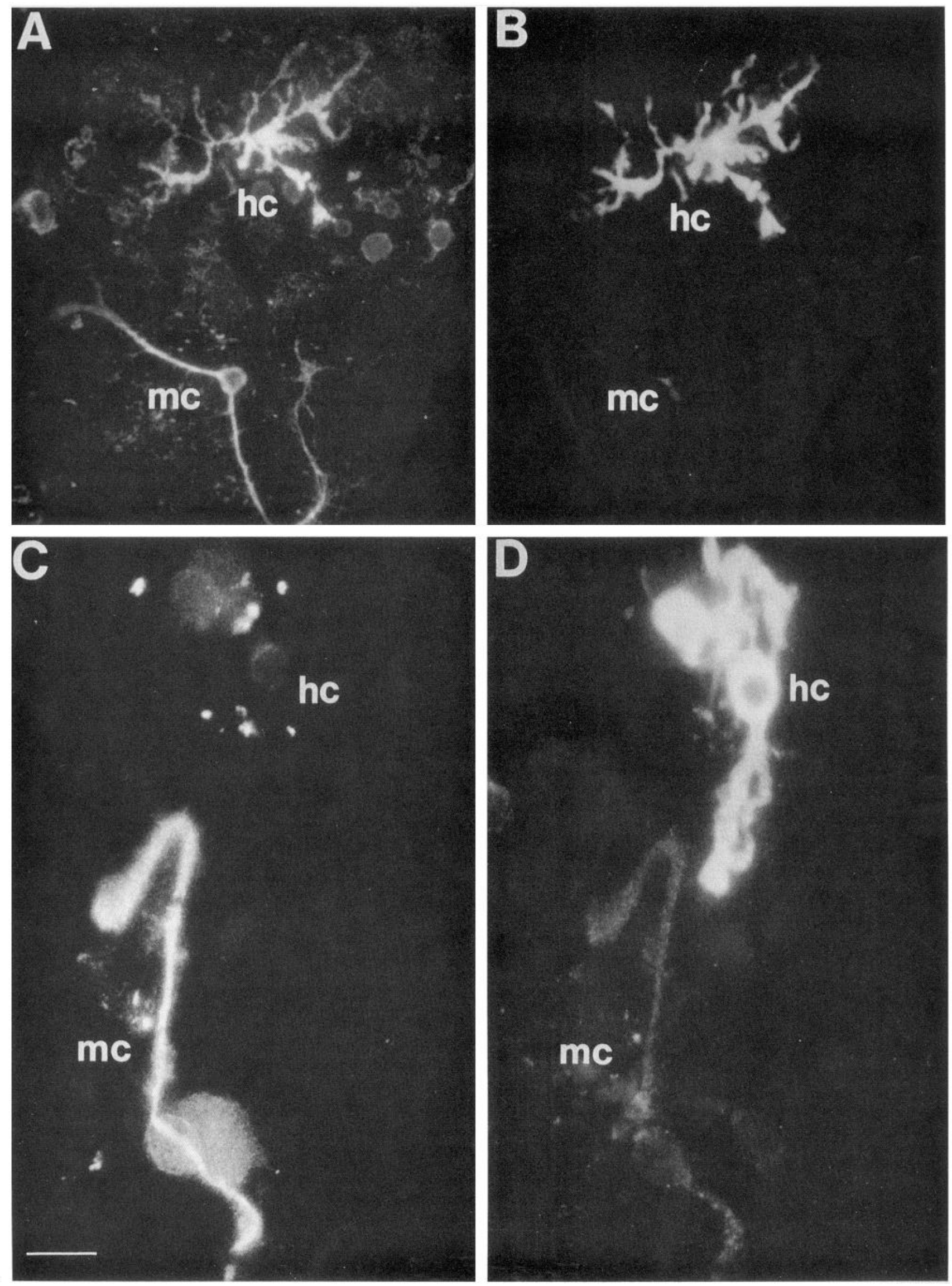

Figure 9. The $165 \mathrm{kDa}$ AE3 isoform is expressed in Müller cells $(m c)$ but not horizontal cells $(h c)$. Dissociated rat retinal cells were stained with antibody AP-3 $(A)$ or AP-6 $(C)$ together with antibody to calbindin $28 \mathrm{k}(B, D)$, which labels only HC. Scale bar, $25 \mu \mathrm{m}$. 
as carbonic anhydrase ${ }^{2}$ and vimentin (Shaw and Weber, 1983; Robinson and Dreher, 1990), normally considered to be glialspecific markers. HC functionally synapse onto cones (Baylor et al., 1971) despite the lack of any ultrastructural evidence of synaptic vesicles (Nicolson and Painter, 1973; Ziparo et al., 1978). Finally, HC of the same subtype are extensively coupled by gap junctions into large networks that serve to effectively increase the size of the visual field over which they can integrate synaptic input (Dowling, 1987; Wassle and Boycott, 1991). Several of these $\mathrm{HC}$ features suggest possible roles for an anion exchanger.

Electrical coupling of $\mathrm{HC}$ in fish (Teranishi et al., 1984) and turtle (Piccolino et al., 1984) retinas via gap junctions is subject to complex regulation by dopamine, acting though a cAMPdependent protein kinase pathway, by cGMP, and by intracellular pH (DeVries and Schwartz, 1989). Horizontal cell gap junctions are steeply inhibited by intracellular protons, within the physiological range, with a $0.2-0.3$ unit decrease in $\mathrm{pH}_{i}$ giving a $50 \%$ decrease in junctional conductance (DeVries and Schwartz, 1989). Tight regulation of horizontal cell $\mathrm{pH}_{i}$ is thus likely to be a crucial factor in the control of $\mathrm{HC}$ coupling. The presence of carbonic anhydrase in $\mathrm{HC}$ together with the magnitude of $\mathrm{CO}_{2}$ production by the adjacent photoreceptors suggests that significant levels of intracellular $\mathrm{HCO}_{3}^{-}$could be produced in horizontal cells. AE3 may contribute to $\mathrm{pH}_{i}$ homeostasis by exchanging intracellularly produced $\mathrm{HCO}_{3}{ }^{-}$with extracellular $\mathrm{Cl}^{-}$.

Anion exchange in HC may also, thus, have implications for the control of intracellular $\mathrm{Cl}^{-}$. Carbon dioxide, released from aerobic metabolism in nearby photoreceptors, could provide a "driving force" for the AE3 anion exchanger to maintain intracellular $\mathrm{Cl}^{-}$above electrochemical equilibrium in $\mathrm{HC}$. This would provide a means for coupling intracellular $\mathrm{Cl}^{-}$in $\mathrm{HC}$ to photoreceptor activity and could have functional consequences for signal processing in the OPL. For example, release of the neurotransmitter GABA from fish horizontal cells occurs via reversal (Schwartz, 1982, 1987; Yazulla and Kleinschmidt, 1983) of a $\mathrm{GABA} / \mathrm{Na}^{+} / \mathrm{Cl}^{-}$cotransporter (Kanner and Schuldiner, 1987; Keynan and Kanner, 1988) that in other cells functions as an "uptake" carrier. The increased intracellular $\mathrm{Cl}^{-}$in $\mathrm{HC}$ could provide an extra driving force, along with depolarization (Schwartz, 1982, 1987), for GABA release from HC that would be highest in the dark when photoreceptor metabolic activity is maximal. Published studies report resting horizontal cell $\mathrm{Cl}^{-}$ equilibrium potential $\left(E_{\mathrm{Cl}}\right)$ near $-20 \mathrm{mV}$ in bicarbonate-free solution (Miller and Dacheux, 1983; Djamgoz and Laming, 1987); it will be important in the future to examine whether $E_{\mathrm{Cl}}$ is sensitive to changes in local $\mathrm{pCO}_{2}$.

\section{Expression of AE3 isoforms during retinal development}

Cell differentiation in the rodent retina proceeds until late into the second postnatal week, correlating with a late onset of retinal function and metabolic activity (Weidman and Kuwabara, 1969; Blanks and Bok, 1977; Carter-Dawson and LaVail, 1979; Young, 1985). Our data establish that neither AE3 isoform is expressed

\footnotetext{
${ }^{2}$ Considerable interspecies polymorphism exists in the retina. In mouse, CAII is detectable in most cell types before birth, but is apparently detectable only in MC and a subpopulation of amacrine cells in the adult retina (Bhattacharjee, 1976; Linser et al., 1984). In chick retina, CAII expression is detectable only in Müller cells (Linser and Moscona, 1981). By contrast, in fish retina, strong CAII immunoreactivity is detectable in both MC and HC (Linser et al., 1985; Vaughn and Lasater, 1990).
}

A.

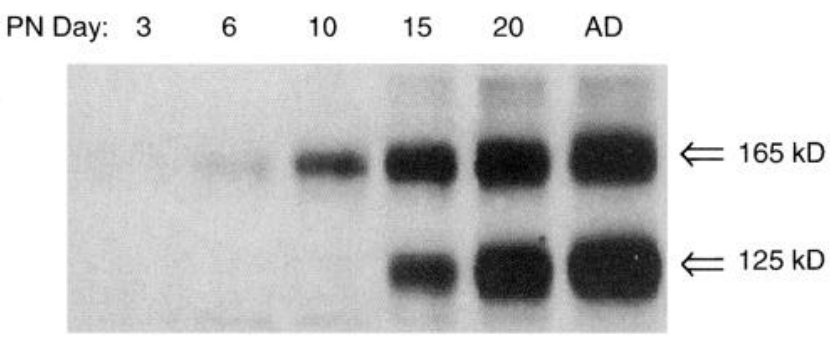

B.

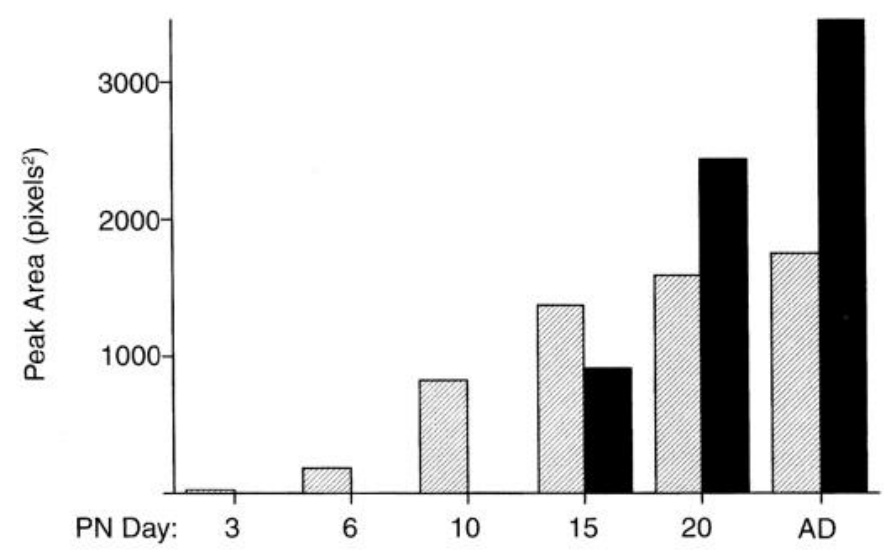

Figure 10. Expression of retinal AE3 isoforms during postnatal development. Each lane of the immunoblot $(A)$ was loaded with identical amounts of total SDS-soluble protein. The blot was probed with antibody AP-3. B, Quantification of the relative intensity of the $165 \mathrm{kDa}$ band (shaded bars) or $125 \mathrm{kDa}$ band (black bars). A shorter exposure of the same blot as in $A$ (which was within the linear range of the detection and quantification) was used to quantify the image.

at detectable levels in the retina at birth, and that the $125 \mathrm{kDa}$ and $165 \mathrm{kDa}$ isoforms of $\mathrm{AE} 3$ accumulate in $\mathrm{HC}$ and $\mathrm{MC}$, respectively, with distinct kinetics. By contrast to the $165 \mathrm{kDa}$ isoform, whose abundance in retina rises steadily with time after birth, the $\mathrm{HC}$ isoform remains completely undetectable until between postnatal days 10 and 15 , when its abundance rises sharply. Thus, we observe a striking coincidence between the appearance of the $\mathrm{HC}$ anion exchanger and the acquisition of retinal function, including eye opening and the onset of electroretinographic responses (Weidman and Kuwabara, 1969). These observations lend support to the proposal that AE3 contributes to the "frontline" defense against the tremendous $\mathrm{CO}_{2}$ load generated from photoreceptor metabolism. To test this hypothesis, it will be important to observe the effects on the retina of blocking the expression or activity of AE3 isoforms during development.

Retroviral lineage mapping studies show that all classes of retinal neurons and Müller glia arise asynchronously from multipotent progenitors (Turner and Cepko, 1987) that are, initially, morphologically indistinguishable. These and other studies indicate that commitment to cell type can occur at, or after, final neuroepithelial cell division, suggesting that cell fate decisions in the retina may depend, at least in part, on "environmental 
factors." Given that the range of environmental factors that have been implicated in cell differentiation in the CNS includes such diverse influences as cell-cell contact (Reh, 1992), diffusible factors (Watanabe and Raff, 1992), and electrical activity (Barres and Raff, 1993), it is conceivable that extracellular or intracellular $\mathrm{pH}$ changes may either directly or indirectly contribute to this process. A sudden rise in the bicarbonate permeability of the $\mathrm{HC}$ plasma membrane could influence the $\mathrm{pH}$ in and surrounding the outer plexiform layer. The expression of $\mathrm{HC}$ AE3 may itself be induced by a sudden burst of metabolic activity and ensuing $\mathrm{CO}_{2}$ generation that must accompany the functional activation of the visual pathway. It will be interesting in the future to identify factors that control the late transcription of the AE3 gene in the retina.

\section{References}

Aickin CC, Brading AF (1982) The effect of $\mathrm{CO}_{2} / \mathrm{HCO}_{3}$ and DIDS on $\mathrm{Cl}$ movements in guinea-pig vas deferens. Proc Physiol Soc Feb:74P$75 \mathrm{P}$.

Badley JE, Bishop GA, St John T, Frelinger JA (1988) A simple, rapid method for the purification of poly $A^{+}$RNA. Biotechniques $6: 114$ 116.

Barnes S, Bui Q (1991) Modulation of calcium-activated chloride current via $\mathrm{pH}$-induced changes of calcium channel properties in cone photoreceptors. J Neurosci 11:4015-4023.

Barres BA, Raff MC (1993) Proliferation of oligodendrocyte precursor cells depends on electrical activity in axons. Nature 361:258-260.

Baylor DA, Fuortes MG, O'Bryan PM (1971) Receptive fields of cones in the retina of the turtle. J Physiol (Lond) 214:265-294.

Bhattacharjee J (1976) Developmental changes of carbonic anhydrase in the retina of the mouse: a histochemical study. Histochem J 8:6370.

Björklund H, Bignami A, Dahl D (1985) Immunohistochemical demonstration of glial fibrillary acidic protein in normal rat Müller glia and retinal astrocytes. Neurosci Lett 54:363-368.

Blanks JC, Bok D (1977) An autoradiographic analysis of postnatal cell proliferation in the normal and degenerative mouse retina. J Comp Neurol 174:317-328.

Bouvier M, Szatkowski M, Amato A, Attwell D (1992) The glial cell glutamate uptake carrier countertransports $\mathrm{pH}$-changing anions. $\mathrm{Na}$ ture 360:471-474.

Cabantchik ZI, Greger R (1992) Chemical probes for anion transporters of mammalian cell membranes. Am J Physiol 262:C803C827.

Cabantchik ZI, Rothstein A (1972) The nature of the membrane sites controlling anion permeability of human red blood cells as determined by studies with disulfonic stilbene derivatives. J Membr Biol 10:31 1330.

Carter-Dawson LD, LaVail MM (1979) Rods and cones in the mouse retina. II. Autoradiographic analysis of cell generation using tritiated thymidine. J Comp Neurol 188:263-272.

Casey JR, Pirraglia CA, Reithmeier RA (1992) Enzymatic deglycosylation of human band 3, the anion transport protein of the erythrocyte membrane. Effect on protein structure and transport properties. J Biol Chem 267:11940-11948.

Celio MR, Heizmann CW (1981) Calcium-binding protein parvalbumin as a neuronal marker. Nature 293:300-302.

Chaillet JR, Amsler K, Boron WF (1986) Optical measurements of intracellular $\mathrm{pH}$ in single LLC-PK1 cells: demonstration of $\mathrm{Cl}-\mathrm{HCO}_{3}$ exchange. Proc Natl Acad Sci USA 83:522-526.

Chen JC, Chesler M (1990) A bicarbonate-dependent increase in extracellular $\mathrm{pH}$ mediated by GABA receptors in turtle cerebellum. Neurosci Lett 116:130-135.

Chesler M (1990) The regulation and modulation of $\mathrm{pH}$ in the nervous system. Prog Neurobiol 34:401-427.

Chesler M, Kaila K (1992) Modulation of $\mathrm{pH}$ by neuronal activity. Trends Neurosci 15:396-402.

Christensen BN, Hida E (1990) Protonation of histidine groups inhibits gating of the quisqualate/kainate channel protcin in isolated catfish cone horizontal cells. Neuron 5:471-478.

Debus E, Weber K, Osborn M (1983) Monoclonal antibodies specific for glial fibrillary acidic (GFA) protein and for each of the neurofilament triplet polypeptides. Differentiation 25:193-23.

DeVries SH, Schwartz EA (1989) Modulation of an electrical synapse between solitary pairs of catfish horizontal cells by dopamine and second messengers. J Physiol (Lond) 414:351-375.

Dixon DB, Takahashi K, Copenhagen DR (1993) L-Glutamate suppresses HVA calcium current in catfish horizontal cclls by raising intracellular proton concentration. Neuron 11:267-277.

Dixon RG, Eng LF (1981) Glial fibrillary acidic protein in the retina of the developing albino rat: an immunoperoxidase study of paraffinembedded tissue. J Comp Neurol 195:305-321.

Djamgoz MB, Laming PJ (1987) Micro-electrode measurements and functional aspects of chloride activity in cyprinid fish retina: extracellular activity and intracellular activities of L- and C-type horizontal cells. Vision Res 27:1481-1489.

Donner K, Hemilä S, Kalamkarov G, Koskelainen A, Shevchenko T (1990) Rod phototransduction modulated by bicarbonate in the frog retina: roles of carbonic anhydrase and bicarbonate exchange. J Physiol (Lond) 426:297-316.

Doolittle RF (1987) Of urfs and orfs: a primer on how to analyze derived amino acid sequences. Mill Valley, CA: University Sciencc Books.

Dowling JE (1987) The retina: an approachable part of the brain. Cambridge, MA: The Belknap Press of Harvard UP.

Dräger UC, Edwards DL, Barnstable CJ (1984) Antibodies against filamentous components in discrete cell types of the mouse retina. $J$ Neurosci 4:2025-2042.

Feinberg AP, Vogelstein B (1983) A technique for radiolabeling DNA restriction endonuclease fragments to high specific activity. Anal Biochem 132:6-13.

Futterman S, Kinoshita J (1959) Metabolism of the retina. I. Respiration of cattle retina. $\mathrm{J}$ Biol Chem 234:723-726.

Gedney C, Ostroy SE (1978) Hydrogen ion effects of the vertebrate photoreceptor. The pKs of ionizable groups affecting cell permeability. Arch Biochem Biophys 188:105-113.

Grinstein S, Rothstein A, Sarkadi B, Gelfand EW (1984) Responses of lymphocytes to anisotonic media: volume-regulating behavior. Am J Physiol 246:C204-C215.

Hebert SC (1986) Hypertonic cell volume regulation in mouse thick limbs. II. $\mathrm{Na}^{+}-\mathrm{H}^{+}$and $\mathrm{Cl}^{-}-\mathrm{HCO}_{3}{ }^{-}$exchange in basolateral membranes. Am J Physiol 250:C920-C931.

Huxlin KR, Sefton AJ, Furby JH (1992) The origin and development of retinal astrocytes in the mouse. J Neurocytol 21:530-544.

Jentsch TJ, Keller SK, Koch M, Wiederholt M (1984) Evidence for coupled transport of bicarbonate and sodium in cultured bovine corneal endothelial cells. J Membr Biol 81:189-204.

Kaila K, Voipio J (1987) Postsynaptic fall in intracellular $\mathrm{pH}$ induced by GABA-activated bicarbonate conductance. Nature 330:163-165.

Kanner BI (1993) Structure and function of sodium-coupled neurotransmitter transporters. Soc Gen Physiol Ser 48:243-250.

Kanner BI, Schuldiner S (1987) Mechanism of transport and storage of neurotransmitters. CRC Crit Rev Biochem 22:1-38.

Keynan S, Kanner BI (1988) $\gamma$-aminobutyric acid transport in reconstituted preparations from rat brain: coupled sodium and chloride fluxes. Biochemistry 27:12-17.

Knauf PA (1986) Anion transport in erythrocytes. In: Physiology of membrane disorders (Andreoli TE, Hoffman JF, Fanestil DD, Schultz SG, eds), pp 191-234. New York: Plenum.

Kopito RR (1990) Molecular biology of the anion exchanger gene family. Int Rev Cytol 123:177-199.

Kopito RR, Lee BS, Simmons DS, Lindsey AE, Morgans CW, Schneider $\mathrm{K}$ (1989) Regulation of intracellular $\mathrm{pH}$ by a neuronal homolog of the erythrocyte anion exchanger. Cell 59:927-937.

Kurtz I, Golchini K (1987) $\mathrm{Na}^{+}$-independent $\mathrm{Cl}\left({ }^{-}\right)-\mathrm{HCO}_{3}{ }^{-}$exchange in Madin-Darby canine kidney cells: role in intracellular $\mathrm{pH}$ regulation. J Biol Chem 262:4516-4520.

Laemmli UK (1970) Cleavage of structural proteins during the assembly of the head of bacteriophage T4. Nature 227:680-685.

Lee BS, Gunn RB, Kopito RR (1991) Functional differences among nonerythroid anion exchangers expressed in a transfected human cell line. J Biol Chem 266:11448-11454.

Li ZP, Burke EP, Frank JS, Bennett V, Philipson KD (1993) The cardiac $\mathrm{Na}^{+}-\mathrm{Ca}^{2+}$ exchanger binds to the cytoskeletal protein ankyrin. J Biol Chem 268:11489-11491.

Liebman PA, Mueller P, Pugh EN Jr (1984) Protons suppress the dark current of frog retinal rods. J Physiol (Lond) 347:85-110. 
Linn SC, Kudrycki KE, Shull GE (1992) The predicted translation product of a cardiac AE3 mRNA contains an $\mathrm{N}$ terminus distinct from that of the brain $\mathrm{AE} 3 \mathrm{Cl}^{-} / \mathrm{HCO}_{3}{ }^{-}$exchanger. J Biol Chem 267: $7927-7935$.

Linser P, Moscona AA (1981) Carbonic anhydrase C in the neural retina: transition from generalized to glia-specific cell localization during embryonic development. Proc Natl Acad Sci USA 78:71907194.

Linser PJ, Sorrentino M, Moscona AA (1984) Cellular compartmentalization of carbonic anhydrase- $C$ and glutamine synthetase in developing and mature mouse neural retina. Dev Brain Res 13:65-71.

Linser PJ, Smith K, Angelides K (1985) A comparative analysis of glial and neuronal markers in the retina of fish: variable character of horizontal cells. J Comp Neurol 237:264-272.

Machen TE, Paradiso AM (1987) Regulation of intracellular pH in the stomach. Annu Rev Physiol 49:19-33.

Mason MJ, Smith JD, Garcia-Soto JJ, Grinstein S (1989) Internal pH-sensitive site couples $\mathrm{Cl}^{-}-\mathrm{HCO}_{3}{ }^{-}$exchange to $\mathrm{Na}^{+}-\mathrm{H}^{+}$antiport in lymphocytes. Am J Physiol 256:C428-C433.

McGrail KM, Sweadner KJ (1986) Immunofluorescent localization of two different $\mathrm{Na}, \mathrm{K}-\mathrm{ATPases}$ in the rat retina and in identified dissociated retinal cells. J Neurosci 6:1272-1283.

McKeon FD, Kirschner MW, Caput D (1986) Homologies in both primary and secondary structure between nuclear envelope and intermediate filament proteins. Nature 319:463-468.

Meyertholen EP, Wilson MJ, Ostroy SE (1986) The effects of hepes, bicarbonate and calcium on the cGMP content of vertebrate rod photoreceptors and the isolated electrophysiological effects of cGMP and calcium. Vision Res 26:521-533.

Miller RF, Dacheux RF (1983) Intracellular chloride in rctinal ncurons: measurement and meaning. Vision Res 23:399-411.

Morgans CW, Kopito RR (1993) Association of the brain anion exchanger, AE3, with the repeat domain of ankyrin. J Cell Sci 105: $1137-1142$.

Nelson WJ, Veshnock PJ (1987) Ankyrin binding to $\left(\mathrm{Na}^{+}, \mathrm{K}^{+}\right)$ATPase and implications for the organization of membrane domains in polarized cells. Nature 328:533-536.

Newman EA (1986a) Regional specialization of the membrane of retinal glial cells and its importance to $\mathrm{K}^{+}$spatial buffering. Ann NY Acad Sci 481:273-286.

Newman EA (1986b) High potassium conductance in astrocyte endfeet. Science 233:453-454.

Newman EA (1986c) The Müller cell. In: Development, morphology, and regional specialization of astrocytes, Vol I (FedoroffS, Vernadakis A, eds), pp 149-171. New York: Academic.

Newman EA (1991) Sodium bicarbonate cotransport in retinal Müller (glial) cells of the salamander. J Neurosci 11:3972-3983.

Nicolson GL, Painter RG (1973) Anionic sites of human erythrocyte membranes. II. Antispectrin-induced transmembrane aggregation of the binding sites for positively charged colloidal particles. J Cell Biol 59:395-406.

Oakley B II, Wen R (1989) Extracellular pH in the isolated retina of the toad in darkness and during illumination. J Physiol (Lond) 419: 353-378.

Piccolino M, Neyton J, Gerschenfeld HM (1984) Decrease of gap junction permeability induced by dopamine and cyclic adenosine $3^{\prime}$ : 5 '-monophosphate in horizontal cells of turtle retina. J Neurosci 4:2477-2488.

Reh TA (1992) Cellular interactions determine neuronal phenotypes in rodent retinal cultures. J Neurobiol 23:1067-1083.

Robinson SR, Dreher Z (1990) Müller cells in adult rabbit retinae: morphology, distribution and implications for function and development. J Comp Neurol 292:178-192.

Rodieck RW (1988) The primate retina. In: Comparative primate biology, Vol 4, Neurosciences. New York: Liss.
Röhrenbeck J, Wässle H, Heizmann CW (1987) Immunocytochemical labelling of horizontal cells in mammalian retina using antibodies against calcium-binding proteins. Neurosci Lett 77:255-260.

Sambrook J, Fritsch EF, Maniatis T (1989) Molecular cloning. A laboratory manual. Cold Spring Harbor, NY: Cold Spring Ilarbor Laboratory.

Sarthy PV, Lam DM (1979) Isolated cells from a mammalian retina. Brain Res 176:208-212.

Schwartz EA (1982) Calcium-independent release of GABA from isolated horizontal cells of the toad retina. J Physiol (Lond) 323:211227

Schwartz EA (1987) Depolarization without calcium can release $\gamma$-aminobutyric acid from a retinal neuron. Science 238:350-355.

Shaw G, Weber K (1983) The structure and development of the rat retina: an immunofluorescence microscopial study using antibodies specific for intermediate filament proteins. Eur J Cell Biol 30:219 232.

Shaw G, Weber K (1984) The intermediate filament complement of the retina: a comparison between different mammalian species. Eur J Cell Biol 33:95-104.

Sidman RL (1961) Histogenesis of mouse retina studies with thymidine- $\mathrm{H}^{3}$. In: The structure of the eye (Smelser GK, ed), pp 487-505. New York: Academic.

Sillman AJ, Owen WG, Fernandez HR (1972) The generation of the late receptor potential: an excitation-inhibition phenomenon. Vision Res 12:1519-1531.

Smith PR, Saccomani G, Joe EH, Angelides K, Benos DJ (1991) Amiloride-sensitive sodium channel is linked to the cytoskeleton in renal epithelial cells. Proc Natl Acad Sci USA 88:6971-6975.

Stone J, Dreher Z (1987) Relationship between astrocytes, ganglion cells and vasculature of the retina. J Comp Neurol 255:35-49.

Takahashi K, Dixon DB, Copenhagen DR (1993) Modulation of a sustained calcium current by intracellular $\mathrm{pH}$ in horizontal cells of fish retina. J Gen Physiol 101:695-714.

Teranishi T, Negishi K, Kato S (1984) Regulatory effect of dopamine on spatial properties of horizontal cells in carp retina. J Neurosci $4: 1271-1280$

Turner DL, Cepko CL (1987) A common progenitor for neurons and glia persists in rat retina late in development. Nature 328:131-136.

Vaughan DK, Lasater EM (1990) Glial and neuronal markers in bass retinal horizontal and Müller cells. Brain Res 537:131-140.

Vaughan-Jones RD (1978) Effect of bicarbonate and SITS on alphaiCl recovery in sheep cardiac Purkinje fibres [proceedings]. J Physiol (Lond) 282:22P-23P.

Walls GL (1942) The vertebrate eye and its adaptive radiation. Bloomfield Hills, MI: Cranbook Institute of Science.

Warburg O (1926) Uber Stoffweschel der Tumoren. Berlin: Springer.

Wassle H, Boycott BB (1991) Functional architecture of the mammalian retina. Physiol Rev 71:447-480.

Watanabe T, Raff MC (1992) Diffusible rod-promoting signals in the developing rat retina. Development 114:899-906.

Weidman TA, Kuwabara T (1969) Development of the rat retina. Invest Ophthalmol 8:60-69.

Yamamoto F, Borgula GA, Steinberg RH (1992) Effects of light and darkness of $\mathrm{pH}$ outside rod photoreceptors in the cat retina. Exp Eye Res 54:685-697.

Yazulla S, Kleinschmidt J (1983) Carrier-mediated release of GABA from retinal horizontal cells. Brain Res 263:63-75.

Young RW (1985) Cell differentiation in the retina of the mouse. Anat Rec 212:199-205.

Ziparo E, Lemay A, Marchesi VT (1978) The distribution of spectrin along the membranes of normal and echinocytic human erythrocytes. J Cell Sci 34:91-101. 